\title{
Regulation, Competition and Bank Risk: Evidence from China
}

\author{
Yachen $\mathrm{Liu}^{1}$ \\ ${ }^{1}$ School of Economics, Jinan University, Guangzhou, China \\ Correspondence: Yachen Liu, School of Economics, Jinan University, Guangzhou, China. Tel: \\ 86-189-2210-0148. \\ Received: March 17, 2017 \\ Accepted: March 28, 2017 \\ Online Published: March 31, 2017 \\ doi:10.20849/abr.v2i1.135 \\ URL: https://doi.org/10.20849/abr.v2i1.135
}

\begin{abstract}
This paper uses the semi-annual data of 16 listed banks from the fourth quarter of 2005 to the second quarter of 2016 as the research sample to study the impact of supervision and competition on the listed bank's risk in China. The results show that the higher level of bank holdings (capital adequacy ratio and core capital adequacy ratio) can significantly reduce the combined risk of banks and increase bank stability. Increased liquidity (liquidity ratio and deposit-loan ratio) can reduce bank risk, but this effect is not significant. The more fierce competition among banks (the smaller CR) will not only increase the proportion of weighted risk assets in total assets, but also increase the bank's bankruptcy probability and reduce the overall operating stability of the bank. It is necessary for authorities of policy to strengthen supervision of banking industry, especially the capital adequacy ratio and core capital adequacy ratio regulation and keep the competition of banks under the appropriate interval. It is also necessary for regulators to comply with the latest regulations of Basel III to set up more reasonable liquidity regulatory indicators to meet liquidity risk management.
\end{abstract}

Keywords: regulation, competition, risk-taking

\section{Introduction}

With three decade of reform of Chinese banking system occurring since the mid-1980s, market structure has undergone a fundamental change, from a highly centralized and unified structure in the past to a system dominated by state-controlled, and small and medium-sized commercial banks as the main body with various shadow banks. At the same time, Chinese government carried out a series of banking supervision regulations, including initially establishing an integrated banking supervision system with a capital adequacy ratio, liquidity ratio and provision rate, and regarding leverage as the main regulatory tool, which improved the internal risk of commercial banks control mechanism. During the basic completion of the interest rate reform, it can be also observed that not only the management level but also the quality of service and performance of commercial banks have improved significantly in the past 30 years. It is still necessary for us to study whether the market structure reform and change of banking regulatory system have improved the performance of micro-entities and reduced their risk-taking level. According to the SCP theory framework established by Harvard University Mason (1939) and Bain (1959), market structure determines the behavior of the enterprise market, which will induce a direct and important impact on the performance and risk-taking level for companies. However, contract to structure conduct performance theory, scholars of institutional economics, such as Williamson O.E. (1983), point that a certain degree of industrial concentration may precisely improve performance of enterprise, thereby in turn enhance the overall performance of industry, rather than lower business performance. What's more, it is interesting for us to further research whether the relation between market structure regulated intensely by government and performance is consistent with the structure efficiency of the SCP framework.

Although a great deal of scholars have further studied the relationship between competition structure under government regulation and performance of banks, there is not a consistent conclusion now. Williams et al. (1994) argues that structure efficiency hypothesis well explains Spanish banking system. Some scholars have found that there is a positive correlation between monopoly and bank performance (Keeley, 1990; Molyneux \&Thornton, 1992). Berger (1995). Ayadi and Ellouze (2013) argue that there is a negative correlation between monopoly and bank performance. It is worth mentioning that these scholars in the measurement of bank performance basically take the financial efficiency indicators into consideration with ignoring the risk control indicators. However, a reasonable evaluation of bank performance should include not only financial performance of banks but also the risk control indicators.

Based on the above understanding and previous research results, this paper take risk control indicator into model 
in order to have a comprehensive evaluation of bank performance. This paper using 16 listed banks in China, focuses on studying the influence of banking regulation and market structure on risk-taking behavior of banks, in order to investigate whether structure efficiency performance framework also applies to China.

The organization of the paper is as follows. The first section provides a small sample of recent literature about the relationship among competition, regulation and bank's performance under the background about Chinese banking industry reform with supervision tools and the SCP theory. The second section develops a formal model centering on competition structure, government regulation and risk-taking behavior of banks. The third section talks about the variables that are used in the empirical analysis, and identifies the data sources for each of these variables. The fourth section presents the results from regressions using fixed effect model. The fifth section is the conclusions made along with social and political implications of the findings.

\section{Literature and Review}

On the relationship between bank competition and bank risk, both in theoretical analysis and empirical analysis, the academic community did not reach a consensus. On the one hand, several scholars agree with "competition-vulnerability hypothesis" which points competition of banking in fact induce instability. Through constructing a two-stage state preference model with deposit insurance system, Keeley (1990) finds that increasing of the degree of competition in the financial service leads to deregulation of deposits rates, which means increasing in bank capital costs, thus reduce the charter value of bank. In order to compensate for the decline of profits, bank managers will engage in high-risk activities harmful for financial stability. This conclusion is supported by Hellmann et al. (2000) and Repullo (2004). Yeyati and Micco (2007) using statistics from 8 Latin American countries, find that due to different products of foreign banks, brand awareness and hidden security, foreign capital infiltration will reduce the degree of competition, then improve the charter value of banks and promote the stability of the financial system.

On the other hand, several scholars agree with "competition-stability hypothesis", which believe that competition leads to stability. It is assumed that the fierce competition in the loan market will reduce the lending rate and the low interest rate will enable borrowers to raise their capital return rate, reduce the financial cost and default risk, and thereby reduce the systemic risk of the banking industry (Boyd and De Nicolo, 2005). In addition, big banks take more risk because they have the chance to get the guarantee from the government. Xiaoqing et al. (2014) using 2003-2010 statistics from 14 Asia-pacific countries finds that the higher concentration of banking will reduce the pricing power of banks, thus encourage banks to take greater risk and deepen financial fragility.

In addition, Martinez and Repullo (2010), on the basis of competitive stability, improved the static equilibrium model and proposed the MMR model. Their research shows that there is a "U"type relationship between competition and financial stability. Under a highly centralized market structure, the risk transfer effect dominates, and under less competitive market structure, the profit marginal effect dominates. Recent research also began to discuss the non-linear relationship between competition and bank risk. Tebak et al. (2012) and Jimenez et al. (2013) demonstrate the conclusion of nonlinear relationship between competition and bank risk. Van Hoose (2007) argues that strict capital regulation prompts banks to replace loans with risky assets with high return on investment, increase bank management costs and affect their profitability Pasiouras et al. (2009) using the stochastic frontier analysis to examine the 615 banks of 74 countries in the year of 2000-2004, points out that under more effective supervision and strict market discipline, banks disclose information more accurately and timely). So strict capital requirements will increase cost efficiency and reduce profit efficiency. Ayadi and Boujelbene (2014) support the moral hazard hypothesis, and argue that capital regulation will reduce bank performance and strengthen financial institutions' liquidity risk management is critical to financial stability.

Several scholars also take market structure and regulation into analyzing the impact on bank performance. Agoraki et al. (2011) study the banking sector of Central and Eastern Europe in the year of 1998-2005 and find that the minimum capital requirement would generally reduce the risk of banks, but for banks with market forces, capital requirements might not only reduce the risk but the level will also encourage banks to engage in high-risk activities, so regulatory authorities of policy need to consider the industry market structure.

\section{Model and Data}

\subsection{Variables and Model}

(1) Bank risk-taking: using two indicators to replace bank risk-taking, the proportion of weighted risk assets in the total assets (SAR) and Z index. The ratio of risk-weighted assets to total assets measures the level of banks' risk from the perspective of portfolio risk. The higher the proportion of weighted risk assets, the higher the current level of risk facing banks. Z-Score reflects the overall risk level of the bank. According to the calculation method of $\mathrm{Z}$ index, ROA is the rate of return on assets, $\mathrm{E} / \mathrm{A}$ is the ratio of equity to assets, $\sigma(\mathrm{ROA})$ is the 
standard deviation of the rate of return on assets(ROA) using 3 rolling method. The higher the Z-Score, the more stable the bank, and the lower the probability of bankruptcy. The calculating method of $\mathrm{Z}$ index as following:

$$
Z_{i t}=\frac{R O A_{i t}+(E / A)_{i t}}{\sigma(R O A)_{i t}}
$$

(2) Bank Capital: The capital adequacy ratio (CAR) and the core capital adequacy ratio (CCAR) are the capital regulatory indicators developed by the Basel Committee, reflecting the extent to which banks can bear the loss of their own capital. On the one hand, the higher level of capital, the higher degree of risk loss that banks can afford to reduce their risk; on the other hand, the higher capital adequacy ratio represents a higher degree of risk aversion to the bank with higher of the risk premium, and thus tend to improve its business performance.

(3) Bank liquidity: This paper uses liquidity ratio (LIQ) and deposit-loan ratio (DL) to measure the liquidity of banks. The liquidity ratio reflects the amount of bank's liquidity assets, and the larger the indicator, the better the liquidity of the bank. The deposit and loan ratio determine the amount of bank loans, the higher the deposit and loan ratio means the insufficient liquidity. In order to maintain their own liquidity banks need to pay the corresponding costs to worse business performance, but with liquidity increasing, the ability of banks to resist risks will be strengthened, so that their risk can be reduced.

(4) Bank Competition: This paper uses the CR index to measure the degree of competition in the banking market, indicating that the proportion of total loan account of each bank in total loan of the banking industry. This indicator indicates that the market share of the market in banking industry, reflecting the market competition in the market of each enterprise. Generally speaking, the higher proportion of loan in the overall loan of banking industry, the bigger market share of individual bank. It is obvious that the low level of competition is beneficial for banks to improve their performance. At the same time, if the number of banks is so small, banks will change their portfolio risk and risk-taking behavior.

In addition, this paper also controls bank-specific variables such as bank provisioning rate (PCR), cost-to-income ratio (CIR) and scale (LNA).The bank provision rate measures the provision for a bank loan loss reserve, which means that the more provision is made, the stronger the ability to resist risks. The higher cost-to-income ratio represents higher operational efficiency, and measures the cost of per unit of input, thereby affects the bank's profitability and risk. Expanding the size of banks can reduce their operating costs and increase bank yields, but may also increase the risk of banks. In addition, the economic environment will directly affect the operating status of country's banks, so this paper selects GDP growth rate and M2 growth rate to reflect the macroeconomic situation and the money supply environment on bank performance and risk behavior. If the circumstances of economic situation is better, the profitability of banks will also increase, and corporate default risk will be reduced, so the bank is facing less risk.

Table 1 shows the definition of research.

Table 1. Definition of research

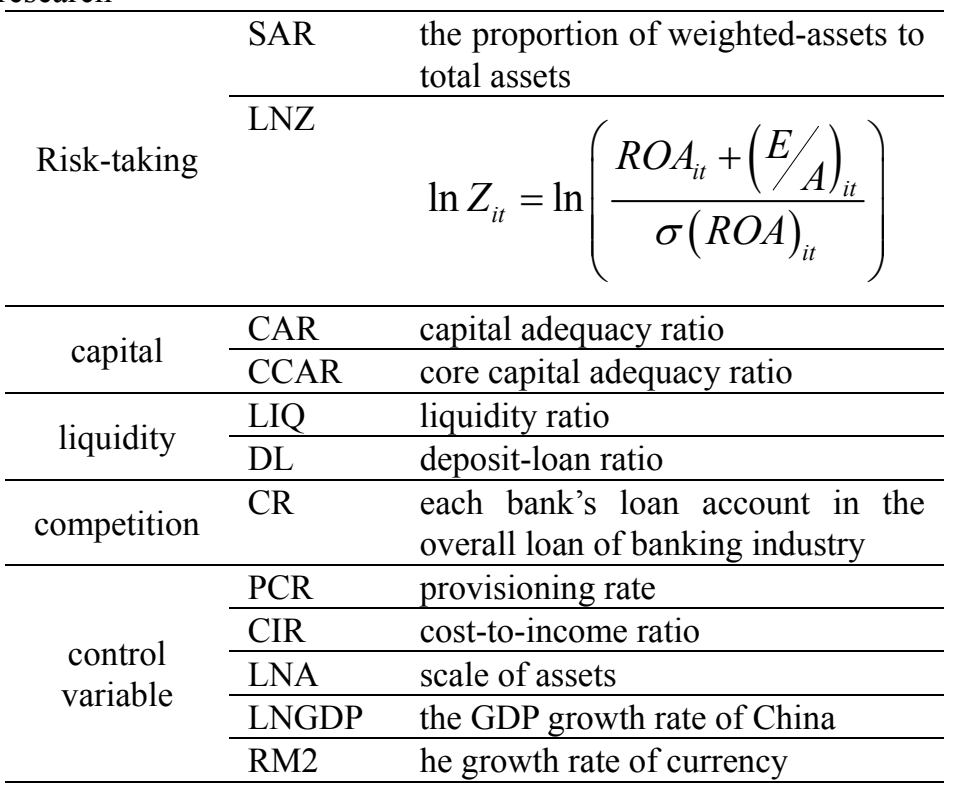


In order to study the impact of bank liquidity, capital and competition on the risk of banks, this paper establishes the following measurement model:

$$
\operatorname{RISK}_{i, t}=\beta_{0}+\beta_{1} \text { Capital }_{i, t}+\beta_{2} \text { Liquidity }_{i, t}+\sum_{k=1}^{5} \text { Control }_{i, t}+v_{i, t}
$$

Risk represents the bank risk variable; Capital $=\{\mathrm{CAR}, \mathrm{CCAR}\}$, represent the bank capital variable $(\mathrm{CAR}$ represents capital adequacy ration and CCAR represents core capital adequacy ratio); Liquidity $=\{\mathrm{LIQ}, \mathrm{DL}\}$, represent the bank liquidity variable(LIQ represents liquidity ratio, Control $=\{P C R$, CIR, LNA, LNGDP, RM2 $\}$, represent all the control variables(PCR represents the provisioning rate of banks, CIR represents cost-to-income ratio, LNA represents scale of banks, LNGDP represents the GDP growth rate of China and M2 represents the growth rate of currency; Competition $=\{\mathrm{CR}\}$, represent the bank competition variable(CR represents each bank's loan account in the overall loan of banking industry).

This paper uses the fixed effect method to estimate above model.

\subsection{Sample and Data}

This paper chooses the semi-annual data of 16 listed banks from the fourth quarter of 2005 to the second quarter of 2016 in China as the research sample. Banks' risk variables, regulatory variables, competition variables, and other control variables are all data from the Wind database, and the availability and authenticity of the data are reliable.

\subsection{Data description and Relevance}

Table 2. Descriptive statistics of main variables

\begin{tabular}{cccccccc}
\hline VARIABLE & MEAN & SD & MIN & P25 & P50 & P75 & MAX \\
\hline SAR(\%) & 59.354 & 6.273 & 44.505 & 54.887 & 59.028 & 63.662 & 73.996 \\
\hline LNZ & 3.094 & 0.270 & 2.238 & 2.931 & 3.091 & 3.240 & 4.127 \\
\hline CAR(\%) & 11.817 & 2.729 & 3.580 & 10.730 & 11.560 & 12.850 & 30.670 \\
\hline CCAR(\%) & 9.321 & 2.773 & 3.680 & 8.120 & 9.300 & 10.450 & 27.380 \\
\hline LIQ(\%) & 43.085 & 9.579 & 23.000 & 36.010 & 42.475 & 48.880 & 79.760 \\
\hline DL(\%) & 67.813 & 6.890 & 42.840 & 62.260 & 69.403 & 72.450 & 84.428 \\
\hline CR(\%) & 4.285 & 4.678 & 0.113 & 1.135 & 2.193 & 4.702 & 16.896 \\
\hline PCR(\%) & 221.848 & 94.628 & 42.771 & 151.220 & 215.950 & 285.170 & 499.600 \\
\hline CIR(\%) & 32.589 & 6.663 & 0.415 & 28.430 & 32.190 & 37.300 & 47.736 \\
\hline LNA & 9.890 & 1.364 & 6.338 & 8.949 & 9.945 & 10.883 & 12.320 \\
\hline LNGDP & 12.508 & 0.499 & 11.466 & 12.128 & 12.491 & 12.903 & 13.364 \\
\hline RM2(\%) & 16.828 & 4.405 & 11.800 & 13.600 & 16.720 & 17.820 & 28.460 \\
\hline
\end{tabular}

Table 2 reports the descriptive statistical results of the main study variables. The proportion of weighted-risk assets in total assets up to $73.996 \%$, in addition, LNZ up to 4.127 , therefore, we can see some of the banks during the sample period have a high risk level. On average, the capital adequacy ratio of $11.817 \%$ has reached the regulatory requirements, but the individual banks still exist capital shortage phenomenon. The minimum liquidity ratio is $23 \%$ and the maximum value is $79.76 \%$.It can be seen that the liquidity difference between different banks is large. Deposit and loan ratio is only $67.813 \%$, and did not meet the previous $75 \%$ of the regulatory standards. The smallest market share of banks is $0.113 \%$, the largest is $16.896 \%$, showing that the market competition between banks in China is not sufficient.

Table 3 reports the Pearson correlation test results. It can be seen from Table 3 that the correlation coefficient between the main variables is below $40 \%$, and there is no serious multiple col-linearity among the variables of this paper. 
Table 3. Pearson correlation test results

\begin{tabular}{|c|c|c|c|c|c|c|c|c|c|c|c|c|}
\hline & SAR & LNZ & CAR & CCAR & LIQ & DL & $\mathrm{CR}$ & PCR & CIR & LNA & LNGDP & RM2 \\
\hline SAR & 1.000 & & & & & & & & & & & \\
\hline LNZ & 0.027 & 1.000 & & & & & & & & & & \\
\hline CAR & $-0.283^{* * *}$ & $0.278^{* * *}$ & 1.000 & & & & & & & & & \\
\hline CCAR & $-0.216^{* * *}$ & $0.304^{* * *}$ & $0.954 * * *$ & 1.000 & & & & & & & & \\
\hline LIQ & 0.024 & 0.016 & $0.131 * *$ & $0.136^{* *}$ & 1.000 & & & & & & & \\
\hline DL & $0.450^{* * *}$ & -0.089 & $-0.291 * * *$ & $-0.344 * * *$ & -0.145 & 1.000 & & & & & & \\
\hline CR & $-0.169^{* * *}$ & 0.070 & 0.135 & 0.149 & -0.113 & -0.278 & 1.000 & & & & & \\
\hline PCR & $0.161^{* * *}$ & $-0.189^{* * *}$ & 0.138 & 0.105 & -0.056 & -0.010 & -0.206 & 1.000 & & & & \\
\hline CIR & -0.081 & $0.121^{* *}$ & -0.337 & -0.358 & -0.070 & 0.152 & -0.142 & -0.319 & 1.000 & & & \\
\hline LNA & $0.158^{* * *}$ & -0.045 & -0.003 & -0.017 & -0.168 & 0.028 & 0.800 & 0.081 & -0.269 & 1.000 & & \\
\hline LNGDP & $0.235^{* * *}$ & $0.115^{*}$ & 0.179 & 0.159 & 0.041 & 0.034 & -0.004 & 0.424 & -0.110 & 0.255 & 1.000 & \\
\hline RM2 & $-0.294^{* * *}$ & -0.016 & -0.113 & -0.132 & -0.125 & 0.060 & 0.001 & -0.347 & 0.312 & -0.214 & -0.355 & 1.000 \\
\hline
\end{tabular}

\section{Empirical Result}

To precisely estimate the impact of regulation especially under the liberation of loan interest rate and deposit interest rate market and competition from banking industry on risk-taking behavior of banks, based on above theoretical analysis, this paper establishes an evaluation model to evaluate using the fixed effect method. The result of evaluation of the fixed effect method can be seen in the Table 4 and Table 5 .

Table 4. The impact of supervision and competition on the listed bank's risk

\begin{tabular}{ccccc}
\hline & $(1)$ & $(2)$ & $(3)$ & $(4)$ \\
& SAR & SAR & LNZ & LNZ \\
\hline CAR & $-0.6727^{* * *}$ & & $0.0299^{* * *}$ & \\
& $(0.1809)$ & & $(0.0051)$ & \\
CCAR & & $-0.4080^{* *}$ & & $0.0349^{* * *}$ \\
& & $(0.1854)$ & & $(0.0063)$ \\
LIQ & -0.0606 & & -0.0034 & \\
& $(0.0452)$ & & $(0.0025)$ & \\
DL & & 0.1347 & & -0.0053 \\
& & $(0.1064)$ & & $(0.0091)$ \\
CR & $-2.1895^{* * *}$ & $-1.7491^{*}$ & $0.1299^{* * *}$ & $0.0907^{* *}$ \\
& $(0.6421)$ & $(0.9081)$ & $(0.0316)$ & $(0.0397)$ \\
PCR & -0.0020 & -0.0015 & $-0.0006^{* *}$ & -0.0005 \\
& $(0.0076)$ & $(0.0068)$ & $(0.0002)$ & $(0.0003)$ \\
CIR & -0.0272 & 0.0027 & 0.0038 & 0.0061 \\
& $(0.0774)$ & $(0.0706)$ & $(0.0063)$ & $(0.0058)$ \\
LNA & $3.5232^{* *}$ & $3.7664^{* *}$ & $-0.1213^{* *}$ & -0.1048 \\
& $(1.3582)$ & $(1.4414)$ & $(0.0564)$ & $(0.0675)$ \\
LNGDP & 0.5266 & 0.0480 & $0.1439^{* * *}$ & $0.1246^{* * *}$ \\
& $(0.7299)$ & $(0.6947)$ & $(0.0290)$ & $(0.0278)$
\end{tabular}




\begin{tabular}{ccccc} 
RM2 & $-0.2234^{* *}$ & $-0.2001^{* *}$ & $-0.0099^{* *}$ & $-0.0077^{* *}$ \\
& $(0.0875)$ & $(0.0882)$ & $(0.0038)$ & $(0.0033)$ \\
_cons & $42.9469^{* *}$ & 27.2710 & $1.9004^{* *}$ & $2.2532^{* *}$ \\
& $(15.5662)$ & $(17.6730)$ & $(0.7092)$ & $(0.9499)$ \\
\hline$N$ & 282 & 273 & 282 & 273 \\
R2 & 0.3755 & 0.3232 & 0.2298 & 0.2430 \\
F value & 10.36 & 11.18 & 63.47 & 14.03 \\
\hline
\end{tabular}

Banks hold more capital (capital adequacy ratio and core capital adequacy ratio) can significantly reduce the combined risk of banks and increase bank stability (LNZ), which is consistent with the risk transfer hypothesis. The higher ratio of the capital adequacy of the bank, the lower the risk level of the bank itself. So there is a reverse relationship between the capital holdings and the bank risk. In the face of capital regulatory constraints, not directly through the increase in level of capital, banks in China often adjust the structure of the weighted-risk portfolio to meet requirements of regulation, thereby reduce the risk of bank portfolio. It can be seen that the regulation of capital adequacy ratio can reduce the risk behavior of Chinese banks.

Increasing liquidity (LIQ and DL) can reduce bank risk, but this effect is not significant. This means that the use of liquidity ratio or deposit-loan ratio of the regulatory measures did not have a significant constraint on the risk behavior of domestic banks. With the increasing liberation level of financial market and the increasingly complex and diversified structure of the banks' assets and liabilities, it is necessary for regulators to comply with the latest regulations of Basel III to set up more reasonable liquidity regulatory indicators to meet liquidity risk management.

The more sufficient competition among banks (smaller CR) will not only increase the weighted- risk assets of banks, but also increase the bank's bankruptcy probability and reduce the overall operating stability of the bank (LNZ), which is in line with competition-fragile hypothesis. Competition -fragile hypothesis argues that the fierce competition among the bank loan market, to a certain extent, will reduce the bank's lending rates and profit margins, and then encourage the bank's risk-taking behavior.

As the bank provision rate (PCR) is improved, the bank reserve is fully utilized to resist risk, and the operating performance (ROA) has a positive impact. Bank size (LNA) will reduce its profitability, but also increase the risk of banks. As China's large banks are mainly state-owned commercial banks, its system is huge, so increasing in size may lead to serious agency problems making bank earnings decline. In addition, the government implicit guarantee breeds moral hazard, and the greater the size of the bank, the greater the possibility of government assistance, that is to say, "big but not down", so large banks have the incentive to engage in high-risk investment and increase risk. Better economic situation (LNGDP) can improve the overall operating performance (ROA) and reduce the bankruptcy probability (LNZ). During the period of economic growth, strong investment in enterprises, expansion of bank investment business, and further increase in profit margins, while the bank's overall bankruptcy risk will be reduced. Higher growth rate of the money supply (RM2) will significantly reduce the net interest margin. In addition, the rapid increasing in money supply (RM2) can reduce bank portfolio risk, but meantime increase the overall bankruptcy risk (LNZ).

Twice adjustment of deposit and lending rate in 2012 and fully liberation of lending interest rate in 2013 means China has gone into the acceleration phase of interest rate market reform. Since banks have more power in pricing, based on the benchmark interest rate on the market, enable banks to fully compete and control their risk level. Based on the time characteristics of China's interest rate reform, this paper divides into the slow period of interest rate reform from 2005 to 2011 and the acceleration period of 2012 to the second quarter of 2016 using dummy variable. That is, if in the time of 2005 to 2011, then dummy variable equal to 0 , otherwise, in the time of 2012 to the second quarter of 2016, dummy variable equal to 1, for investigating whether the impact of supervision and competition on risk-taking behavior of banks have difference under different stage of liberation of interest rate.

Table 5 reports the result of impact of regulation and competition on bank's risk-taking level under different interest rate reform stage in China. It can be seen that under the phase of liberation of interest rate, competition can reduce the combination of banks' risk. However, lending interest rate reform enables banks have the rights to self-pricing in market, but also allows banks to face more uncertainty, including interest rate risk and banks need to hold more capital to resist such risk. Furthermore, the liberation of interest rate in China strengthens the 
competition level of banking industry. That is, if banks hold more liquidity assets, the deposit cost will directly limit the ability to increase net interest margin of banks. At the same time, banks need to reduce their lending rate to attract borrowers, thereby in turn reduce the profitability of banks. Then liberation of interest rate enables banks fall into greater risk exposure, and banks need to maintain a higher level of capital to maintain their reputation.

Table 5. The impact of regulation, competition on bank risk-taking under interest rate liberation

\begin{tabular}{|c|c|c|c|}
\hline & (5) & (6) & (7) \\
\hline & SAR & SAR & SAR \\
\hline \multirow[t]{2}{*}{ CAR } & $-0.6569^{* * *}$ & $-0.6577^{* * *}$ & $-0.6840^{* * *}$ \\
\hline & $(0.1667)$ & $(0.1644)$ & $(0.1746)$ \\
\hline \multirow[t]{2}{*}{ CAR*DUM } & $0.1645^{* *}$ & & \\
\hline & $(0.0684)$ & & \\
\hline \multirow[t]{2}{*}{ LIQ } & -0.0669 & $-0.0853^{*}$ & $-0.0740^{*}$ \\
\hline & $(0.0420)$ & $(0.0421)$ & $(0.0410)$ \\
\hline \multirow[t]{2}{*}{ LIQ* DUM } & & $0.0470^{*}$ & \\
\hline & & $(0.0242)$ & \\
\hline \multirow[t]{2}{*}{$\mathrm{CR}$} & $-1.7221^{* *}$ & $-1.8306^{* * *}$ & -1.1766 \\
\hline & $(0.6300)$ & $(0.6082)$ & $(0.8245)$ \\
\hline \multirow[t]{2}{*}{$\mathrm{CR}^{*} \mathrm{DUM}$} & & & $0.2496^{*}$ \\
\hline & & & $(0.1198)$ \\
\hline \multirow[t]{2}{*}{ PCR } & -0.0011 & -0.0005 & -0.0029 \\
\hline & $(0.0073)$ & $(0.0072)$ & $(0.0073)$ \\
\hline \multirow[t]{2}{*}{ CIR } & -0.0137 & -0.0210 & -0.0188 \\
\hline & $(0.0745)$ & $(0.0770)$ & $(0.0727)$ \\
\hline \multirow[t]{2}{*}{ LNA } & $2.4437^{*}$ & 2.1919 & $3.2012^{* *}$ \\
\hline & $(1.3863)$ & $(1.4049)$ & $(1.3428)$ \\
\hline \multirow[t]{2}{*}{ LNGDP } & 0.5204 & 0.6339 & 0.4957 \\
\hline & $(0.7221)$ & $(0.7231)$ & $(0.7294)$ \\
\hline \multirow[t]{2}{*}{ RM2 } & $-0.1592^{* *}$ & $-0.1605^{* *}$ & $-0.1975^{* *}$ \\
\hline & $(0.0681)$ & $(0.0739)$ & $(0.0846)$ \\
\hline \multirow[t]{2}{*}{ _cons } & $49.2689^{* * *}$ & $51.7103^{* * *}$ & $41.9236^{* *}$ \\
\hline & (15.6248) & (15.7618) & (15.3538) \\
\hline$N$ & 282 & 282 & 282 \\
\hline R2 & 0.3878 & 0.3883 & 0.3877 \\
\hline F value & 11.01 & 11.56 & 9.90 \\
\hline
\end{tabular}

\section{Conclusion}

This paper uses semi-annual data of 16 listed banks from the fourth quarter of 2005 to the second quarter of 2016 as the research sample to study the impact of supervision and competition on the listed bank's risk in China. The results show that the higher level of bank holdings (capital adequacy ratio and core capital adequacy ration) can significantly reduce the combined risk of banks and increase bank stability (LNZ).Increased liquidity (liquidity ratio and deposit-loan rate) can reduce banks' risk, but this effect is not significant. The more fully competition among banks (the smaller CR) will not only increase the proportion of weighted-risk assets in total assets (SAR), but also increase the bank's bankruptcy probability and reduce the overall operating stability of the bank (LNZ). 
The results of the impact of regulation and competition on risk-taking behavior under different stage of liberation shows that liberation of interest rate has increased the level of competition among banks, although the banks' own market share reduction will increase bank risk, but under the liberation of interest rate market background, competition can reduce the combination of banks' risk. However, interest rate reform enables banks to have the rights to self-pricing, but also allows banks to face more uncertainty, including interest rate risk and banks need to hold more capital to resist risk. It is necessary for authorities to strengthen supervision of banking industry and keep the competition of banks under the appropriate interval. It is also necessary for regulators to comply with the latest regulations of Basel III to set up more reasonable liquidity regulatory indicators to meet liquidity risk management.

\section{References}

Ayadi, N., \& Boujelbene, Y. (2014). The role of capital regulation on bank performance. International Journal of Managerial and Financial Accounting, 6(3), 203-226. https://doi.org/10.1504/IJMFA.2014.065239

Bain, J. S. (1951). Relation of Profit Rate to Industry Concentration, American Manufacturing 1936-1940. The Quarterly Journal of Economics, 65(4), 293-324. https://doi.org/10.2307/1882217

Berger, A. N. (1995). The Profit-Structure Relationship in Banking-Tests of Market-Power and Efficient-Structure Hypotheses. Journal of Money, Credit and Banking, 27(2), 404-431.

Boyd, J. H., \& Nicolo, G. D. (2005). The Theory of Bank Risk-taking and Competition. Journal of Finance, 60(2), 1329-1343. https://doi.org/10.1111/j.1540-6261.2005.00763.x

Fu, X. Q., \& Heffernan, S. (2009). The Effects of Reform on China's Bank Structure and Performance. Journal of Banking and Finance, 33(1), 39-52. https://doi.org/10.1016/j.jbankfin.2006.11.023

Fu, X. Q., Lin, Y. J., \& Molyneux, P. (2014). Bank Competition and Financial Stability in Asia Pacific. Journal of Banking and Finance, 38, 64-77. https://doi.org/10.1016/j.jbankfin.2013.09.012

Hellmann, T. F., Murdock, K.C., \& Stiglitz, J. E. (2000). Liberalization, Moral Hazard in Banking, and Prudential Regulation, Are Capital Requirements Enough?. The American Economic Review, 90(1), 147-165. https://doi.org/10.1257/aer.90.1.147

Jimeneza, G., Lopezb, J. A., \& Saurinaa, J. (2013). How does competition affect bank risk-taking?, Journal of Financial Stability, 9(2), 185-195. https://doi.org/10.1016/j.jfs.2013.02.004

Keeley, M. (1990). Deposit Insurance, Risk, and Market Power in Banking. The American Economic Review, 80(5), 1183-1200.

Kim, D., \& Santomero, A. M. (1988). Risk in Banking and Capital Regulation. The Journal of Finance, 43(5), 1219-1233. https://doi.org/10.1111/j.1540-6261.1988.tb03966.x

Llody-Williams, D. M., Molyneux, P., \& Thornton, J. (1994). Market structure and performance in Spanish banking. Journal of Banking and Finance, 18(3), 433-443. https://doi.org/10.1016/0378-4266(94)90002-7

Martinez-Miera, D., \& Repullo, R. (2010). Does Competition Reduce the Risk of Bank Failure?. The Review of Financial Studies, 23(10), 3638-3664. https://doi.org/10.1093/rfs/hhq057

Mason, E. S. (1939). Price and Production Policies of Large-scale Enterprise. The American Economic Review, 29(supplement), 61-74.

Repullo, R. (2004). Capital requirements, market power, and risk-taking in banking. Journal of Financial Intermediation, 13(2), 156-182. https://doi.org/10.1016/j.jfi.2003.08.005

Tabak, B. M., Fazio, D.M., \& Cajueiro, D. O. (2013). The relationship between banking market competition and risk-taking, Do size and capitalization matter?. Journal of Banking and Finance, 36(12), 3366-3381. https://doi.org/10.1016/j.jbankfin.2012.07.022

Van Hoose. D. (2007). Theories of bank behavior under capital regulation. Journal of Banking and Finance, 31(12), 3680-3697. https://doi.org/10.1016/j.jbankfin.2007.01.015

\section{Copyrights}

Copyright for this article is retained by the author(s), with first publication rights granted to the journal.

This is an open-access article distributed under the terms and conditions of the Creative Commons Attribution license (http://creativecommons.org/licenses/by/4.0/). 